\title{
Activating Farmers : Uses of entrepreneurship discourse in the rhetoric of policy implementers
}

\section{Pyysiäinen, Jarkko}

2013

Pyysiäinen , J \& Vesala , K 2013 , ' Activating Farmers : Uses of entrepreneurship discourse in the rhetoric of policy implementers ', Discourse \& Communication, vol. 7 , no. 1 , pp. 55-73 . https://doi.org/10.1177/1750481312466475

http://hdl.handle.net/10138/234018

https://doi.org/10.1177/1750481312466475

acceptedVersion

Downloaded from Helda, University of Helsinki institutional repository.

This is an electronic reprint of the original article.

This reprint may differ from the original in pagination and typographic detail.

Please cite the original version. 


\section{Cover sheet}

Name of the journal the paper is submitted to:

Discourse \& Society

Title of the paper:

Activating farmers:

Uses of entrepreneurship discourse in the rhetoric of policy implementers.

\section{Short title:}

Activating farmers.

Size of paper in words:

8679

Character count (with spaces): 58569

First (and corresponding) author: Jarkko Pyysiäinen

Institutional address:

MTT Agrifood Research Finland

Latokartanonkaari 9

00790 Helsinki

Finland

Tel. +358 406721997

Email: jarkko.pyysiainen@mtt.fi

Private address:

Franzeninkatu 5B 54

00500 Helsinki

Finland 
Second author: Kari Mikko Vesala

Institutional address:

Department of Social Research (Social Psychology)

University of Helsinki

P.O. Box 54

00014 University of Helsinki

Finland

Tel. +358 919124893

Email: kari.vesala@helsinki.fi

Address for proofs and offprints:

Jarkko Pyysiäinen

MTT Agrifood Research Finland

Latokartanonkaari 9

00790 Helsinki

Finland

Tel. +358406721997

Email: jarkko.pyysiainen@mtt.fi

Fax: +358 20772040 


\section{Bionote}

Jarkko Pyysiäinen (M.Soc.Sc.) is a researcher at MTT Agrifood Research Finland, and a doctoral student in the Department of Social Research (Social Psychology) at the University of Helsinki. His current research deals with collaborative and communicative construction of attitudes and agency, and the social psychology of entrepreneurship.

Kari Mikko Vesala (D.Soc.Sc.), Academy Research Fellow at the University of Helsinki, Department of Social Research. Dr. Vesala has studied social psychology of entrepreneurship, small business, and farming. His research interests also include theories of control and agency in social psychology. 


\section{Abstract}

Research on entrepreneurship as a policy discourse has focused mostly on relations between the discourse and targets of the policy, that is actors intended to become entrepreneurial or entrepreneurs, while the role of policy implementers has received much less attention. The present study examines the 'rationality' of entrepreneurship policies by analyzing, how actors in charge of the grass roots level policy implementation in the farm context use entrepreneurship discourse and argue for the communicative and interactive viability of their mission. The analysis of stances and positioning in interview talk reveals that policy implementers are active discourse users who, on the one hand, are able to reflect on the dilemmas and problems inherent in their task but, on the other hand, use their rhetorical agency to maintain and defend their mission as promoters of entrepreneurship policy and to save and support their own face as experts. As a result, the implementation emerges as a delicately managed interaction process. 


\section{Keywords}

Entrepreneurship discourse, rhetorical social psychology, policy

implementation, expertise, entrepreneurial governance, farming 


\section{Activating farmers:}

\section{Uses of entrepreneurship discourse in the rhetoric of policy implementers}

\section{Introduction}

Contemporary Western societies put a lot of effort and expectations on boosting entrepreneurship and the supply of potential entrepreneurs. The idea of enhancing the economy by influencing the orientations of individuals (citizens, employees, and the unemployed) and releasing their 'entrepreneurial', initiative and self-steering capacities figures as a cornerstone in many influential societal discourses. An early version of such discourse was articulated, for instance, in the enterprise culture -program of Margaret Thatcher's government in the UK in 1970's (Heelas and Morris, 1992). Nowadays entrepreneurship promotion seems to have become established as a premise of public policy rather widely throughout societal sectors, from entrepreneurship education and social entrepreneurship to the new entrepreneurship policy (see e.g. Audretsch and Beckman, 2007; Chell, 2007; Della-Giusta and King, 2006; Gilbert et al., 2004; Peters, 2001). These policy discourses typically assume that entrepreneurship as an initiative, autonomous and innovative orientation of actors can, and indeed ought to, be facilitated through policies and programs implemented, e.g., through educational fostering of the 
supply of initiators of business ventures, encouragement of entrepreneurial orientations in individuals and organizations, raising of awareness and creation of incentives and attraction around business opportunities.

The proliferation of entrepreneurship discourses has inspired also scholarly interest towards their operation and impact. For example, critical and interpretive approaches (Jones and Spicer, 2009: 10-26; Ogbor, 2000; Armstrong, 2001; Hjorth and Steyaert, 2004) have questioned the idea that the diffusion of entrepreneurship discourses would be a straightforward process without its troubles. On the one hand, studies of this type have intended to show that the targets of entrepreneurship discourses interpret, evaluate and actively use the discourses for their own purposes, implying that discourses do not mechanically bring forth 'entrepreneurial selves' (Jones and Spicer, 2009: 10-26; Armstrong, 2001). On the other hand, studies have pointed out that entrepreneurship discourses nevertheless tend to favor some fractions of the population at the cost of others, which means that not all individuals have equal opportunities to enter, internalize or cultivate the discourse (Jones and Spicer, 2009: 10-26, Ogbor, 2000). Research on the area makes thus divergent claims concerning the agency of the targets vis-á-vis the discourse, and the power of the discourse to subjugate its targets. However, thus far the research has been fairly convergent in its analytical scope, which has tended to focus on the relationships between the discourse and the targets. Consequently, even 
though entrepreneurship discourses have been studied from the perspective of policy implementation, the actions of policy implementers in the diffusion of the discourse have received rather little attention ${ }^{1}$. The role of the implementers calls for elaboration, especially in the light of the observation that problems in policy implementation often culminate in differing interpretations that implementers, decision makers and targets have of the goals, means and rationales of a policy (Grin and Van de Graaf, 1996; see also Niska and Vesala, 2011). The interpretations and actions of the grass roots level policy implementers may turn out to be crucial in this respect: they are the interface between the discourse and its targets.

The general importance of the role played by implementers and other intermediate agents in the diffusion of discourses has been thematized, albeit in a special way, under influential social scientific theorizing informed by 'governmentality' approach (Burchell et al., 1991; Miller \& Rose, 2008; Dean, 2010). Governmentality theorizing portrays the entrepreneurship policy implementation as relying on and operating through the legitimacy of expert discourses. The implementers are correspondingly portrayed as experts who figure as important mediators in the process of fitting entrepreneurial ideas

\footnotetext{
${ }^{1}$ Research on SME businesses, for instance, has focused on the relationship between implementers and entrepreneurs but not from the perspective of entrepreneurship discourse (Curran, 2000; however, for an example of discursive approach, see Niska and Vesala, 2011). Approaches inspired by 'governmentality' perspective, in turn, tend to focus more generally on the role of 'experts' and 'expertise' (Herbert-Cheshire and Higgins, 2004; Miller and Rose, 2008; Dufty, 2011).
} 
and discourses in with the world of ideas of individual actors (e.g. Rose, 1992, 1993; Miller \& Rose, 2008; Dean 2010). Thus, experts (including business counselors and advisors, coaches, trainers and so on) and expert discourses should be tightly intertwined with the rationale and practices of entrepreneurship policy implementation.

As noted, entrepreneurship policies are being implemented widely throughout societal sectors, under differing contexts and circumstances. Consequently, also the category of policy implementers includes a variety of different kinds of actors that operate in varying conditions. Hence, even though one can point out contexts and conditions that seem to follow closely expert -driven entrepreneurial governance depicted by governmentality theorizing, one can ask whether this is always the case. Should every entrepreneurship policy implementer, even in contexts that have traditionally remained peripheral to entrepreneurial ideas and principles, resemble experts who fluently master the individualistic entrereneurship discourse and eagerly promote it? If critical studies on entrepreneurship discourse have questioned the assumption that the targets of the discourse be bound to passively subjugate to the discourse, could not also the policy implementers be viewed in a similar vein, as active discourse users capable of demonstrating independent agency and discourse use according to their own, even critical, interpretations or purposes? 
In this article we focus on the role of policy implementers in the diffusion of entrepreneurship discourse. Utilizing an analytical approach informed by rhetorical social psychology, we make an empirical excursion to a societal context that, having long enjoyed state protection, is currently under strong pressures to adopt an increasingly entrepreneurial orientation, namely agriculture and farming (Phillipson et al., 2004). In this context, we explore how local and regional implementers of entrepreneurship policy in rural Finland make sense of the rationale of their task and argue for it. Our aim is to analyze, on the one hand, in what sense could one consider the implementers as active discourse users (Burr, 1995) who also make their own interpretations of the policy objectives and implementation (Grin and Van de Graaf, 1996; Spillane et al., 2002), and, on the other hand, to what extent their rhetoric conforms to the basic ideas of entrepreneurship discourse.

\section{'Governmentality', experts and their role in the implementation of entrepreneurship discourses}

More light can be shed on the rationale of entrepreneurship discourse policies by reflecting on it from the perspective of influential theorizing informed by the Foucauldian notion of governmentality (Foucault, 1991; see also Burchell et al., 1991; Dean, 2010; Rose et al., 2006). This strand of theorizing has a special angle on the 
influence and appeal of entrepreneurship ideal: it suggests that the governance of liberal market democracies and their complex social, economic and political processes cannot be based on simple authoritative or disciplinary formulas of rule; instead the governance resorts to and relies on the self-steering, enterprising capacities of individuals. Contrary to the traditional, common-sensical notion of governing, the 'advanced liberal' mode of governing is said to operate through, and not despite or against, the 'powers of freedom' and the autonomy of its subjects. (Rose, 1993, 1999; Miller and Rose, 2008; Dean, 2010.) In elucidating the 'mentality' of particular modes of governance, the governmentality approach focuses on analyzing the specific forms of representation and intervention constitutive of those particular governmental rationalities. As summarized by Lemke (2001: 191):

'For a political rationality is not pure, neutral knowledge which simply 're-presents' the governing reality; instead, it itself constitutes the intellectual processing of the reality which political technologies can then tackle. This is understood to include agencies, procedures, institutions, legal forms, etc., that are intended to enable us to govern the objects and subjects of a political rationality.' 
Viewed from such a perspective, we can argue that also entrepreneurship policy discourses exhibit a particular mentality of government in the way they represent, conceptualize and structure socio-economic reality according to a distinctive formula, which, in turn, should enable the policy makers and programs to intervene in social processes and the realities of potential entrepreneurs. Reflecting on this, entrepreneurship policies obviously adhere to the key principles characteristic of 'advanced liberal' (Rose 1999; Miller and Rose 2008: 199-218; Dean 2010: 175-200) or 'entrepreneurial' (Du Gay, 1996a, 1996b) governance. In terms of the representation aspect, they seek to 'translate' objectives/problems of governing into questions of autonomous self-governance of (quasi-) autonomous agents. In terms of their form of intervention, they typically seek to forge alignments between objectives of political/administrative authorities and personal projects of autonomous agents, e.g. individual citizens. (See Rose, 1992; 1993; 1999; Du Gay, 1996a, 1996b; Lemke, 2001: 201-203; Miller and Rose 2008: 199-21.) In a sense, the enterprising subject who autonomously strives to actualize its own potentials could be viewed as the building block of an 'entrepreneurial' mentality of government or policy.

Since we focus on the implementation of entrepreneurship policy in the context of farming, our crucial question concerns the actors, means and processes through which the implementation is likely to take place. Governmentality approach suggests an 
answer: the intervention capacity in an 'advanced liberal' rationality is viewed as residing on an important intermediate level between the political decision-making and the subjects of governance, on expert agents, i.e. the experts and professionals in the acknowledged position to make 'politically neutral' truth claims and speak for the best interest of each and all (Rose, 1992, 1993, 1999: 137-166; Herbert-Cheshire and Higgins, 2004; Miller and Rose, 2008). The political and administrative authorities as such do not have the access to the powers and means of expert discourse (the truth claims and the legitimacy of professional knowledge) with which to act upon the actions of the governed and to persuade them to release their self-steering capacities. Hence, they seek to mobilize defined forms of expertise, which can be authorized and held accountable to plan and implement procedures vis-à-vis the subjects of government. The intervention capacity is thus made possible and realized by a proliferation of expertise and associated discourses, practices and techniques that merge with the projects of selfmastery and aspirations of the subjects of government. (See Rose, 1992, 1993, 1999; Herbert-Cheshire and Higgins, 2004; Miller and Rose, 2008; Dean, 2010.)

Returning to our research question, governmentality approach may thus help us understand how the aspirations of authorities and targets of government might be brought into alignment under entrepreneurial governance. In this governance, expert agents who promote entrepreneurship discourse sympathetically are crucial. However, 
some disagreement seems to prevail concerning the locus and degree of agency granted in governmentality theorizing (and Foucauldian approaches more generally): Is agency solely located in the discourse, even to the extent that the subjects of the discourse emerge as inherently passive and their actions as determined by the discourse? Critical studies on entrepreneurship discourse, for instance, have argued and intended to show that the targets of the discourse do actively question, resist or creatively use the discourse also in other ways than intended (Jones \& Spicer, 2009). The targets may, for example, harness the discourse for the pursuit of their own purposes that may be completely different from the ones of entrepreneurship discourse; or they may agree on the ends of entrepreneurship discourse but pursue them by means of other discourses (Watson, 2009).

The cited research has focused on the targets of the discourse. However, it is possible to raise the question that if the targets can be viewed as active discourse users who demonstrate agency, why could this not be the case with the implemeters of the policy as well? If the targets are able to reflect on the discourse critically, then would not it be expected from the implementers to be aware of the possible agency of the targets? The implementers are social actors who enagage in social interaction with the targets. Thus, their very task as implementers suggests that they would be able to consider at least the possibility of critical reflection on the entrepreneurship discourse. 
To tackle these questions we examine how the actors in charge of the grass roots level entrepreneurship policy implementation actually use entrepreneurship discourse and how they make sense of their task as promoters of this discourse. On the empirical level, we turn to the context of farming where entrepreneurship policy has gained increasing influence but also competing policy discourses exist (Potter and Tilzey, 2005; Phillipson et al., 2004). Thus, the implementation of entrepreneurship policy, or the promotion of entrepreneurship discourse, is not the only task familiar to the implementers of rural and agricultural policy, although they are expected to be competent expert players also in this role. In our approach we utilize discursive and rhetorical social psychology, especially the viewpoints related to stance taking (e.g. Billig, 1991: 142-167) and reflexive and interactive positioning (Davies and Harré, 2001: 264-267; Harré and Van Langenhove, 1999). We proceed, first, by briefly describing a research project and its results, and then illustrating the aspects of entrepreneurship discourse use in a detailed analysis of a group interview.

\section{Background: findings of a research project}

Our empirical example is part of a qualitative interview data corpus generated in a research project (“On-farm business diversification in municipal rural development 
policy") carried out by the University of Helsinki and MTT Agrifood Research

Finland. ${ }^{2}$ The data was collected in two municipalities in Eastern Finland during 2004 and 2005. Because of the agricultural restructuring, many lines of primary production are no longer profitable in the region, and farms are encouraged to redirect their activities. The data was generated by interviewing a wide array of relevant actors and stakeholders involved in the development of farm businesses (farmers, entrepreneurs, municipal officials, local/regional professionals). However, in this study we focus on the interviews with actors involved in policy implementation, i.e. provision of financial, advisory, and training services for farmers (representatives of municipality, Pro Agria Advisory Center, Employment and Economic Development Center and vocational education institutions).

The approach in generating and analyzing interview data is informed by the principles of rhetorical social psychology, as developed especially by Michael Billig and colleagues (Billig, 1987, 1991; Billig et al., 1988) and elaborated on in the 'qualitative attitude approach' (Vesala and Peura, 2005; Vesala and Rantanen, 2007; Pyysiäinen, 2010). ${ }^{3}$ In conducting interviews we worked along a two-step process. In the first

\footnotetext{
${ }^{2}$ A more detailed summary of the project appeared in a Finnish report (Vihinen and Vesala, 2007).

${ }^{3}$ Qualitative attitude approach includes a particular strategy for conducting semi-structured interviews and generating argumentative talk, as well as an analytic strategy in which systematic analysis of stands and justifications is complemented with interpretive contextual perspectives (Vesala and Rantanen, 2007).
} 
interview round we conducted individual interviews $(\mathrm{N}=23)$ that focused on the stances towards the facilitation and development of entrepreneurship/businesses on farms. Four questions were used as prompts (Speer, 2002) to stimulate comments and conversation: What has been done to facilitate business diversification on farms in your municipality? By whom? What ought to be done to facilitate business diversification on farms? By whom?

The prompts were presented one by one to the interviewees, both verbally and in printing. The interviewees were requested and encouraged to freely comment on them; the interviewers participated by asking for clarifications and further accounts, but refrained from taking stand themselves. Consequently, each question was followed by a discussion lasting from five to fifteen minutes. As prompts for stimulating comments, these questions allowed the interviewees full freedom to choose the direction of their comments. Nevertheless, the formulation of the questions was such that they implicitly assumed the desirability of business development efforts. Thus, one might think that the preferred conversational turn (Pomerantz, 1984) would be to comply with this assumption, and that it would require an effort to disagree. Interestingly, the analysis of the first round interviews ${ }^{4}$ revealed that even though the general tone of commenting was favorable towards business development on farms, several interviewees (most of

\footnotetext{
${ }^{4}$ In both interview rounds the interviews were transcribed verbatim, applying a notation procedure that allows analytical observations on conversational interaction (see Appendix).
} 
whom were farmers) spontaneously expressed reservations and dismissive opinions, thus doubting the tacit assumption of business development desirability inbuilt in the questions. On the whole, then, the interviewees expressed affirmative and dismissive attitudes concerning the goals, means and actors (e.g. investment subsidies, counseling and training activities, and networks) involved in the business development. Taken together, the diversity of affirmative and dismissive opinions revealed by the analysis showed that the common-sensical entrepreneurship discourse/rhetoric used by the interviewees was indeed controversial and laden with dilemmas (Billig, 1991; Billig et al., 1988).

The controversial topics identified in the analysis of individual interviews were then reformulated as prompts to stimulate further commenting in the second interview round which consisted of six group interviews. The discussions in group interviews were prompted by altogether nine prompts expressing the most salient topics revealed by the analysis of individual interviews. For example, (nr. 4) 'Business diversification on farms is best facilitated through training, counseling and information'. And (nr. 6) 'Business diversification on farms depends merely on the farmers themselves. The facilitation should thus be left up to the activity of the farmers'. 
The analysis of the group interviews, in turn, showed that also the implementers, not only the farmers, were well able to express and consider arguments and viewpoints that are critical or skeptical towards entrepreneurship promotion and its measures. Furthermore, the implementers did aim to overcome these controversies by presenting solutions to the dilemmas taken up. In this way, they actively engaged in justifying their basic mission as policy implementers. In the following empirical excursion we demonstrate how all this can be seen in a group interview.

\section{An excursion to a group interview with policy implementers}

The main line of this section is formed by the analysis of the rhetorics in a group interview (G1) among four implementers, all representing municipal and regional organizations, as they illustratively articulate the generic stances towards the facilitation of entrepreneurship on farms. The essential qualitative variation of the argumentation is depicted as three attitudes, each composed of a stance and related justifications. The 'attitudes' are analytical abstractions that capture the core of the variety of evaluative stands taken by the interviewees in their commenting. In the spirit of rhetorical social psychology (Billig, 1987, 1991, 1997; Billig et al., 1988; Vesala and Rantanen, 2007), the attitudes can be viewed as relative to each other and hence revealing the quality of the argumentative field and the essential dimensions of controversy and consensus 
surrounding a topic (i.e. 'entrepreneurship policy implementation' in this case). Further, in the group interview setting the analysis traces the expression of these stances as embedded in the interactional dynamics of the conversation. The rhetorical construction of the stances is therefore further interpreted from the perspectives of facework (Goffman, 1967) and discursive positioning (Davies and Harré, 2001; Harré and Van Langenhove, 1999; Wetherell, 1998).

\section{The farmers need to be activated by external expert intervention}

A prominent attitude expressed by the policy implementers asserts that farmers need to be activated into entrepreneurship by external interventions, performed by external agents (such as the interviewees themselves). They justified this by arguing that external intervention brings out tacit entrepreneurial potential that may otherwise remain hidden. An illustrative formulation of this attitude is observable during the early stages of the discussion through the use of a peculiar metaphor. Interviewee $\mathrm{G} 1 \mathrm{I}^{5}$, a representative of an advisory service center comments on the interview stimulus number two, a statement suggesting that the development of on-farm businesses suffers from the

\footnotetext{
${ }^{5}$ The codes used in the excerpts indicate the identity of the group (e.g. G1 = Group interview 1) and the identity of the interviewee in question (e.g. I1 = Interviewee 1). Interviewers are referred to with capital letters (e.g. Interv. A).
} 
dominance of food processing -related activities in the region. In the words of the speaker, there is a need to 'kick the farmers in the pants' in order to get them oriented towards new business opportunities. In the following excerpt this metaphor comes up for the first time ${ }^{6}$ :

\section{Excerpt 1}

G1 I1: Well yes, in this case it is definitely so that these other ((business opportunities)) remain in the shadow of food processing. Of course food processing is damn good but you would find an awful lot of competences and resources among farmers in ((our municipality)) as well as in other places, if you just had the time to provide support and to kick the farmers in the pants. After all it all depends very much on encouragement, and the development often culminates in projects which focus on food processing. But because of that the farmers play down their other ideas like well I don't dare because it is not considered important. It is like that that the ideas will not come out if there are no projects that would

\footnotetext{
${ }^{6}$ Since the interviews were originally in Finnish, also the verbatim transcription and analysis were done in Finnish. Only the excerpts presented here were translated into English, with the attempt to maintain the original nuances, colloquial expressions and rhythms of speech as much as possible (see Appendix).
} 
foster them. If there were enough time and effort there would indeed be potential resources. And as a matter of fact only the sky is the limit. - - So that would only require that there would be some kicking in the pants and, of course people are so different that some have more courage to bring themselves to the front, and there are anyway very competent persons among those who are more quiet and have not much to say for themselves and that would require some digging or otherwise they will never get out into the open.

In Excerpt 1, the interviewee resorts to an appealing and popular usage of entrepreneurship discourse where entrepreneurship emerges as an emancipating solution for each and all, for the individual as well as for the community. With this usage he justifies his stand towards the interview prompt at hand: much could be done to facilitate entrepreneurship that is not limited to mere food processing, if external agents only devoted more time and effort to activate and encourage farmers. When interpreted from the perspective of discursive positioning, we see that such an evaluative stand and its justifications function to construct subject positions both for the implementers and for the farmers. The implementer is reflexively positioned (Davies and Harré, 2001: 264-267) as a kind of 'socio-psychological expert', whose task is to influence and affect 
the mentality of the targets of policy. The position closely resembles the role of an expert portrayed in 'governmentality' literature. The farmers as targets of the discourse/policy, in turn, are interactively positioned (Davies and Harré, 2001: 264-267) as yet passive and unenterprising ('play down', 'don't dare') but nevertheless as latently competent and very potential entrepreneur-candidates ('only the sky is the limit').

This attitude, where the decisive task of the implementers is represented as catalytic external intervention, functions not only as a premise that promotes external social influence but also legitimates (Fairclough, 2001: 76-77) it. As the external catalytic intervention is justified by appealing to the hidden potentials and obstacles that remain disclosed from the farmers themselves, the implementers claim to be acting for the best interest of the farmers. Legitimation of such a task is thus not drawn from handed-down policy programs, for example, but from the conditions of the targets.

A bit later on in the discussion the Interviewee G1 I1 returns to the importance of external intervention. At this point, however, also the other interviewees join in a collaborative construction of the attitude:

Excerpt 2 
G1 I1: It is a question] of sparring the farmers then,

G1 I2: Well yeah] of course yes [((short laughs in the background $))]$ in order to get them activated, [G1 I3: Awakened.] all activation measures are important,

Excerpt 2 contains several brief comments and interchanges by three different speakers, all of whom contribute to constructing the attitude. Interviewee G1 I1 starts by repeating his earlier stand with a novel and less provocative metaphor drawn from the world of sports: 'sparring'. Interviewee G1 I2 replies with an approval and goes on to take up a similar metaphor, 'activation'. ${ }^{7}$ During this approving comment, also interviewee G1 I3 intervenes briefly in the discussion and expresses her agreement by adding still one more metaphor, 'awakening'. Although different in tone, all of these metaphors depict intervention as a form of social influence.

During the conversation the participants thus co-constructed a generic attitude according to which external intervention is needed to release entrepreneurial potential of the farmers. The manifestation of this attitude was rich and diverse during the whole interview; it was expressed by several interviewees and in relation to several of the

\footnotetext{
${ }^{7}$ As a matter of fact, in the contemporary policy parlance the notion of 'activation' (e.g. Dean, 1995) has probably already passed the passage from metaphor to idiom (Billig \& MacMillan, 2005).
} 
interview prompts. It should be noted that the attitude is thus not reducible to any single prompt presented to the interviewees. Furthermore, the expressions of this attitude were common also in other implementer interviews in our data.

\section{External intervention does not apply equally to all farmers}

If we rewind the conversation a little and refocus on it immediately after the turn-take described in Excerpt 1 (i.e. between Excerpts 1 and 2), we notice that the interviewees in fact start developing and elaborating a counter argument, a particularization (Billig, 1987: 118-155), to the previous attitude. Excerpt 3 focuses on this rhetorical intersection.

Excerpt 3

G1 I2: - - I think that it's such a question that the entrepreneurs who develop their own farms in terms of conventional agriculture may be active in the development of other business opportunities as well. In my view it is a question of entrepreneurs, and of the issue that the farms that we want to get to diversify their businesses are 
those who cannot make the living by means of mere agricultural production alone. They need these additional activities but there is the problem that either the entrepreneur lacks the required characteristics, lacks the required competences or he does not want it, or he already has some other jobs to do. Or he is already at such an age when he does not even take it up. Those who most acutely would need the business diversification are not necessarily able to carry it out. This is the biggest problem. [The conversation continues from here with the reply from G1 I1 shown in Excerpt 2]

Interviewee G1 I2, a representative of another local expert organization, redirects the line of argumentation and thereby reconstructs the category of the targets of intervention (farmers). In his view there are, on the one hand, entrepreneurial farmers who have already managed to 'develop their own farms in terms of conventional agriculture', and, on the other hand, 'those who cannot make the living' by mere agricultural production. This distinction introduces a particularization (Billig, 1987) into the interactive positioning (Davies and Harré, 2001) of the targets. As such, the stand taken by G1 I2 does not totally negate the first attitude, instead it specifies the interactive positioning of the targets by constructing two additional categories (in addition to the 'latently 
potential' targets): the active ones and those who lack potential. The 'biggest problem', noted by the interviewee, concerns the idea of encouraging entrepreneurship among those who lack potential. Further, intervention may not be needed at all in the case of the 'active' farmers.

The criticism included in this comment could be interpreted as a caution against an aim to diffuse entrepreneurship to all farms and farmers, in other words, a caution that was commonly raised by farmers in the interviews of the same project (see Pyysiäinen, 2010). Such a caution could be raised on the basis of critical studies on entrepreneurship discourse (Jones and Spicer, 2009) or rival political discourses that warn against the harmful effects that one-sided or over-enthusiastic entrepreneurship discourse may bring, for instance, from the perspective of equality, equal opportunities and equal treatment. In the context of farming, such a criticism could be connected at least to two politically delicate questions: Is it right to tempt farmers away from the world of conventional agriculture to take up other kinds of businesses? And how should one help or support those farmers who are not willing or able to take up entrepreneuring as a solution to the tightening competition and economic hardship?

If the interviewees would pick up these implicit seeds of critique, fundamental questions of the mission and positioning of the implementers themselves could easily be raised, 
for example, concerning their legitimacy or mandate to engage in singling out certain entrepreneur candidates at the cost of others. Interestingly, however, the speakers do not take up or even comment on such lines of argument, but collaboratively shift the discussion away from that kind of criticism. We observe them dealing with the counterargument inbuilt in Excerpt 3 either by resorting to dispositional rhetoric (e.g. Augoustinos et al., 2006: 157) that acknowledges the existence of individual, endogenous differences between farmers, or by depicting the catalytic intervention as an interactive process where the efforts of the expert-implementer and farmer meet halfway. Both types of arguments function to moderate the 'activation' enthusiasm characteristic of the previous attitude and acknowledge that there are limits to external intervention: it does not apply equally to all farmers.

In Excerpt 4, the point is expressed in the words of Interviewee G1 I4, an official of the municipality:

Excerpt 4

G1 I4: $\quad$ Yes, I suppose there are only few of those farmers who would come directly to our office and say that I take up this or that, it is not like that. It is more likely to happen so that the farmer has 
read somewhere, or heard that one could take up such things, maybe something seems worth trying and a little interest starts to rise and it awakens the farmer to the situation that maybe this thing could be for me. And he starts to ask around how this would work and so on and that's how it gets started then.

The interviewee argues that a typical case where farm businesses take off is a setting where the farmer's own active effort and the advice of the expert-implementer meet half-way, in a situation where the target is suitably susceptible to external influence. Evidently, such cases do not fall into the category of farmers who are 'predestined' entrepreneurs nor into the category of entrepreneurially 'hopeless' cases. Instead, a category of farmers with a potential for entrepreneurship is maintained in the conversation.

The dispositional rhetoric characteristic of this line of stance-taking admits that external intervention is not to be attempted equally or blindly to all farmers. Thereby the implementers are able to discount their own responsibility for the entrepreneurial initiatives eventually undertaken or turned down by farmers. Thus, the rhetoric functions to maintain face (Goffman, 1967: 6-7) of the implementers: eventual futility of the intervention efforts targeted at 'hopeless' cases would, among other things, 
threaten their professional credibility and reputation. Again, the implementers demonstrate rhetorical initiative: they do not resort to publicly delineated policy programs but justify their stands by drawing on more nuanced exemplifications and categorizations of farmers and entrepreneurs.

\section{Accentuation of external intervention questions the autonomy of the farmer}

We showed above that the second attitude raised a caution against the omnipotence of external intervention, even though the original objective and rationale expressed in 'activation' attitude was not denied. Nevertheless, a certain tension, or a source of dilemmas (Billig et al., 1988), could be observed in the rhetorical intersection where the particularization occurred. As noted, at that point the interviewees did not take up the 'equality' -arguments, for instance, but tried to solve the dilemma by invoking a new set of justifications and new categorization of the targets (farmers). However, later in the conversation the interviewees encountered an additional dilemma that stems from the way they particularized the targets as a response to the first dilemma: the second dilemma concerns now the mode of intervention and the management of the relationship between implementers and their targets. If the appropriate targets of intervention are constructed as autonomous and already equipped with nascent entrepreneurial initiative, 
then the accentuation of external intervention may contradict or undermine this individual autonomy and initiative. At the later stages of the group interview this dilemma manifests in the form of an episode of meta-communication when Interviewee G1 I1 once again appeals to the peculiar intervention metaphor, 'kicking in the pants':

\section{Excerpt 5}

Comment on interview stimulus nr. 6: "Business diversification on farms depends merely on the farmers themselves. The facilitation should thus be left up to the activity of the farmers."

G1 I1: - - If you besides the regular counseling chats had a chance to do some activation effort with that bunch, then you would get an awful lot out of them, I mean it requires a kind of external kicking in the pants. - - Mere effort of the farmers is not quite enough for them to make it. In some cases you need simply some psychological encouraging so that things go on as usual, and some sparring and encouraging are needed that something new would be created and also that the former would be maintained.

G1 I2: That is not included in the report this kicking in the 
[pants ((laughing))]

Everybody: [((Laughing $))]$

Interviewer A: Definitely it will be included, it has been repeated so many times, [((laughs)) ]

Everybody: [((Laughing)) ]

Once Interviewee G1 I1 has again expressed the original 'activation' -attitude and repeated the associated metaphors, Interviewee G1 I2 suggests that the metaphor 'kicking in the pants' should be cut out from any reports to be published. Even though the comment is accompanied with laughter and obviously made jokingly, the controversial - and potentially pejorative - aspects and subject positions are thereby made explicit to all participants. Following the classic conversation analytic question we may ask, why this utterance or rhetorical move here (cf. Wetherell, 1998: 388)? An answer is suggested by the evolving rhetorical situation and argumentative context: the interchange described in Excerpt 5 occurs in a situation where the original 'activation' stance has been specified with a set of counter-arguments and particularizations. The interviewees have also been oriented to the reconstructed and better suited subject positions for the targets and for themselves (cf. Wetherell, 1998: 401). However, the interchange in Excerpt 5 now reveals that the abrupt metaphor can be read as a violation against these reconstructed particularizations and subject positions. It risks positioning 
the farmer-target through deficiencies of character, ability and agency, and seriously endangers the objective of the expert-implementers to help farmers experience themselves as active and autonomous entrepreneurial agents.

The immediately following turn, taken again by the originator of the dubious metaphor (G1 I1), provides us with a corrective reframing of and specification to the exaggerating impression of external intervention:

Excerpt 6

G1 I1: It is merely illustrative [Interviewer A: yes.] perhaps it is like encouraging what there ought to be done, and like inspiring, perhaps inspiring is the synonym, substitute for this kicking in the pants.

The interviewee responds to the 'criticism' by trying to clarify the intended impression. The metaphor 'kicking in the pants' should indeed be taken only as a benevolent metaphor, not as an accurate description of the positioning and relationship between implementers and farmers, and rather be replaced by notions like 'encouraging' or 'inspiring'. 
The implementers were readily able to explicate the rationale behind such a communicative reframing. As commented by an implementer in another group interview, the facilitation of entrepreneurship on farms 'must be done, step by step in the long run, and without ((the farmer)) himself noticing the development efforts', because 'when you get him to comprehend the issue himself then it is the thing that it's his own idea'. The second counter-argument thus specifies the mode of the intervention as relying on non-communication (Bateson and Bateson, 1988) of the impression of external influence. Instead, as tactfully reframed, the act of intervention ought to communicate the impression of farmer him/herself as the true origin of the ideas and actions taken up as a consequence of interactions. As this third attitude functions to shift the responsibility for the facilitation of entrepreneurship from the implementer to the target, also the possibility of psychological reactance (Brehm and Brehm, 1981) on the part of the target is reduced. This altogether contributes to the success potential of external policy interventions. Furthermore, with the rhetorical reformulation used to construct the third attitude, the implementers are also able to take into account and preserve the core points of both previous attitudes.

\section{Discussion and conclusions}


In the empirical section we analyzed the rhetoric of four Finnish policy implementers operating in the farm sector, as they engaged in a group interview on the facilitation of entrepreneurship on farms. In the spirit of rhetorical social psychology (Billig, 1987; Billig et al., 1988) we focused on analyzing how the implementers commented on the implementation of entrepreneurship policy The analysis showed that the overarching generic attitude, which continued to flavor the discussion throughout the whole interview, was well in line with entrepreneurship policy discourse. The core point of this 'activation' -attitude claimed that the farmer population should be activated and encouraged to entrepreneurship by means of external interventions, since this activation may release tacit entrepreneurial, self-steering potential for the benefit of each and all. The important role of the policy implementers themselves as the providers of catalytic external activation and encouragement was thereby emphasized

However, a set of counter-arguments and ideological dilemmas (Billig et al., 1988) were encountered in conversation. These counter-arguments and dilemmas were collaboratively tackled and deliberated which resulted in the construction of two particularizations, or counter-attitudes, to the initial 'activation' -attitude. As such, the two counter-attitudes did not totally negate the 'activation' -attitude but rather specified and moderated it. The first counter-attitude problematized the representation of the targets of the policy: since differences exist between farmers but there is no 
unambiguous way to identify the 'true targets' of the policy, it was admitted that activation may not apply to all farmers equally. Instead, the policy implementation was viewed as something partially dependent on the endogenous dispositions and agency of the targets as well as on an interactive process with the expert-implementers. The second counter-attitude, in turn, further problematized the nature of external 'activation' as a form of interactive social influence, given that the endogenous agency of the targets was acknowledged as the precondition for successful diffusion of entrepreneurship discourse. However, the implementers were able to recognize and articulate what their own task as implementers of entrepreneurship policy requires in this respect: the occurrence of external intervention should not be emphasized but the interactions should contribute to an impression where the target is the origin of entrepreneurial actions and ideas.

On the basis of this three-part attitude pattern constructed in the rhetoric of the implementers, we are in a position to answer the research questions we posed at the beginning of the article. First, concerning the question whether the implementers, too, could be considered as active discourse users (Burr, 1995) who make their own interpretations of the entrepreneurship policy objectives, the analysis showed that this indeed was the case. The entrepreneurship discourse was no simple or unproblematic issue for the implementers. Instead, they showed rhetorical initiative when making 
sense of the discourse, its objectives and dilemmas, and their own task as its implementers. On the outset, the implementers were enthusiastic and competent users of entrepreneurship discourse, as the overarching 'activation' -attitude indicates. However, their activity and independence as discourse users manifested in the way they actively problematized the discourse and identified ideological dilemmas that stemmed from the practical task of social influence. Furthermore, the implementers actively engaged in solving the identified dilemmas: they articulated preconditions - and a practical 'blueprint' - on the basis of which the task of entrepreneurship policy implementation in farm context remained feasible and executable task. In particular, the peculiar 'noncommunication' -strategy articulated a solution with which the dilemmas of entrepreneurship discourse could be managed and the objective of its implementation preserved. As an articulation of the rationale of entrepreneurship policy discourse it was a creative interpretation, co-constructed in the course of interactive argumentation. ${ }^{8}$

The answer to our second research question, then, continues and further elaborates this point. Since the implementers, after all, stayed loyal to the entrepreneurial activation ethos and did not give up the objectives of influencing the mentality of the targets (their self-steering, self-confidence and self-concept), their rhetoric thus complies with the basic ideas of entrepreneurship discourse. Indeed, the rhetoric dealt more with 'soft'

\footnotetext{
${ }^{8}$ It should be noted, however, that the three-part attitude pattern was not limited only to the analyzed group interview, but similar attitudes were constructed throughout the interview data.
} 
people management aspect than 'hard' technical aspects of business management. The articulation of their task was thus consonant with the key objectives of entrepreneurship discourse, i.e. influencing the orientations of individuals in order to release their 'entrepreneurial', initiative and self-steering capacities. However, the implementers were able to follow the discourse only by actively, and also critically, re-articulating it. And when re-articulating the discourse, they also demonstrated conscious and independent argumentative effort: they distanced themselves from the discourse, problematized it and took it to directions that cannot be read from the discourse itself, or seen as dictated by it. In these specific occasions it was shown that the distancing and the re-articulations of the discourse were done by appealing to observations, counterarguments and objectives derived from the situations and relationships familiar to the implementers from their implementation activity. The rationale for questioning the objective that all farmers actually should be the targets of the policy or the precept that implementation actually ought to be made tacitly cannot be read or interpreted from the entrepreneurship discourse itself. Instead, these preconditions were shown to be related, on the one hand, to the need of the implementers to legitimate (Fairclough, 2001: 7677) their mission as intervening experts and save their faces and professional credibility as expert-implementers, and on the other hand, to save and maintain the face of the farmer-targets (Goffman, 1967: 5-45). A failure in either of the tasks would seriously 
question the success potential of their interventions. ${ }^{9}$ In talk the orientation to these multiple tasks manifested in situationally shifting and increasingly nuanced discursive positions, constructed by the implementers both for themselves and their targets. In other words, in the course of the conversation the implementers moderated their own interventive role through changes in reflexive positioning (Davies and Harré, 2001: 264-267) and gradually augmented the agency of the target through changes in interactive positioning (Davies and Harré, 2001: 264-267).

The finding, then, that the implementers did not abandon the entrepreneurship discourse despite its obvious challenges but stayed loyal to its basic mission, brings us back to the discussions concerning the role of experts in 'entrepreneurial' or 'advanced liberal' governance (see du Gay, 1996a; Rose, 1992, 1993, 1999; Herbert-Cheshire \& Higgins, 2004; Miller \& Rose, 2008; Dean, 2010) as thematized in 'governmentality' literature. First of all, the rhetoric of the implementers portrayed the implementer him/herself as a crucial expert-agent that makes possible the challenging task of diffusing entrepreneurship discourse in farm context. Such a portrayal resonates strongly with the images of 'entrepreneurial' or 'advanced liberal' governance, where the experts are viewed as crucial intermediate agents between the policy discourse and its targets. Second, and even more to the point from 'governmentality' perspective, was the finding

\footnotetext{
${ }^{9}$ The implementers can thus be viewed as serving simultaneously several goals, the goals of the entrepreneurship discourse and those that are crucial for their careers or reputation as experts, a feature that can be viewed as characteristic to modern secularized agency (Meyer and Jepperson, 2000).
} 
that the implementers acknowledged that the execution of their interventive role depends crucially on the harnessing of the autonomous agency of the targets (e.g. noncommunicating the aspect of external intervention) and of 'forging of alignments' between policy objectives and the personal aspirations of the individual targets (Rose, 1999, especially pp. 47-51). As governmentality theorizing suggests, the entrepreneurial governance in farm context was thus depicted as something relying on expert interventions, yet operating through and not against the freedoms and initiatives of its targets. However, in the farm context, this was only part of the picture. The other part concerned the aspect of intervention as a problematic social interaction process, since not all targets were viewed as willing or able to harness their freedoms for entrepreneurship. A key problem for the implementers concerned the condition that it will not suffice to just help farmers to actualize their own autonomy and potentials, unless they really actualize them in the form of viable businesses. This mutual vulnerability was shown to be an important practical and social precondition that made the implementation complicated - and perhaps more complicated than could be assumed on the basis of 'governmentality' -inspired literature.

Taken together, the analysis showed that the active agency of the implementers emerged as crucial for the diffusion of entrepreneurship discourse and as something that is not quite captured in terms of any simple opposition between a deterministic force of 
discourse versus their autonomous use by active agents. Instead of one-sided, hegemonic social influence or even manipulation (Storey, 2005: 478), the diffusion could be better understood as active negotiation and interaction, where the distributed discourse and subject positions may also be contested and transformed in the course of the implementation. In this respect, the role of the implementers comes close to the view of the targets as active discourse users, as emphasized in the critical studies on entrepreneurship discourse (Jones and Spicer, 2009). Also the implementers were shown to be capable of questioning, resisting or creatively using the discourse in other ways than the discourse would prescribe. However, their active role seemed to be crucial also in maintaining the legitimacy and internal coherence of the discourse: when an ideological dilemma concerning the selection of the appropriate targets for the policy was implicated, for example, the implementers avoided taking any arguments on board concerning the harmful effects of entrepreneurship discourse diffusion, such as violation of the premises of equality or (re)production of relationships of domination (Jones and Spicer, 2009). Hence, we suggest that an analysis directed towards the position of and discourse use practiced by policy implementers may, in many important respects, contribute to sharpening the picture of the operation and preconditions of socio-political discourses and their diffusion. 


\section{References}

Armstrong P (2001) Styles of illusion. Sociological Review 49 (2): 155-173.

Audretsch DB and Beckmann IAM (2007) From small business to entrepreneurship policy. In: Audretsch DB, Grilo I and Thurik RA (eds) Handbook of Research on Entrepreneurship Policy. Cheltenham: Edward Elgar, 36-53.

Augoustinos M, Walker I and Donaghue N (2006) Social Cognition: An Integrated Introduction ( $2^{\text {nd }}$ ed.). London: Sage.

Bateson G and Bateson MC (1988) Angels Fear: Towards an Epistemology of the Sacred. New York: Bantam.

Billig M (1987) Arguing and Thinking: A Rhetorical Approach to Social Psychology. Cambridge: Cambridge University Press.

Billig M (1991) Ideology and Opinions: Studies in Rhetorical Social Psychology. London: Sage. 
Billig M, Condor S, Edwards D, Gane M, Middleton D and Radley A (1988)

Ideological Dilemmas: A Social Psychology of Everyday Thinking. London: Sage.

Billig M and MacMillan K (2005) Metaphor, idiom and ideology: The search for 'no smoking guns' across time. Discourse \& Society 16: 459-480.

Brehm SS and Brehm JW (1981) Psychological Reactance: A Theory of Freedom and Control. New York: Academic Press.

Burchell G, Gordon C and Miller P (eds) (1991) The Foucault Effect: Studies in Governmentality. London: Harvester Wheatsheaf.

Burr V (1995) An Introduction to Social Constructionism. London: Routledge.

Chell E (2007) Social enterprise and entrepreneurship: Towards a convergent theory of the entrepreneurial process. International Small Business Journal 25: 5-26.

Curran J (2000) What is small business policy in the UK for? Evaluation and assessing small business policies. International Small Business Journal 18 (3): 36-50. 
Davies B and Harré R (2003) Positioning: The discursive production of selves. In Schiffrin D, Tannen D and Hamilton HE (eds), The Handbook of Discourse Analysis. Malden, MA: Blackwell, $261-271$.

Dean M (1995) Governing the unemployed self in an active society. Economy and Society 24: 559-583.

Dean M (2010) Governmentality: Power and Rule in Modern Society ( $2^{\text {nd }}$ ed.). London: Sage.

Della-Giusta M and King Z (2006) Enterprise culture. In: Casson M, Yeung B, Basu A and Wadeson N (eds) The Oxford Handbook of Entrepreneurship. Oxford: Oxford University Press, 629-647.

Doolin B. (2002) Enterprise discourse, professional identity and the organizational control of hospital clinicians. Organization Studies 23: 369-390.

Du Gay P (1996a) Organizing identity: Entrepreneurial governance and public management. In: Hall S and du Gay P (eds) Questions of Cultural Identity. London: Sage, 151-169. 
Du Gay P (1996b) Consumption and Identity at Work. London: Sage.

Dufty R (2011) Governing the experts: Reforming expert governance of rural public housing. Australian Geographer 42(2): 165-181.

Fairclough N (2001) Language and Power ( $2^{\text {nd }}$ ed.). London: Longman.

Foucault M (1991) Governmentality. In: Burchell G, Gordon C and Miller P (eds) The Foucault Effect: Studies in Governmentality. London: Harvester Wheatsheaf, 87-104.

Gilbert BA, Audretsch DA and McDougall PP (2004) The emergence of entrepreneurship policy. Small Business Economics 22: 313-323.

Goffman E (1967) Interaction Ritual. Chicago: Aldine.

Grin J and van de Graaf H (1996) Implementation as communicative action: An interpretative understanding of interactions between policy actors and target groups. Policy Sciences 29: 291-319. 
Harré R and van Langenhove L (eds) (1999) Positioning Theory. Oxford: Blackwell.

Heelas P and Morris P (eds) (1992) The Values of the Enterprise Culture. The Moral Debate. London: Routledge.

Herbert-Cheshire L and Higgins V (2004) From risky to responsible: Expert knowledge and the governing of community-led rural development. Journal of Rural Studies 20: 289-302.

Hjorth D and Steyaert C (eds) (2004) Discursive Approaches in Entrepreneurship. Cheltenham: Edward Elgar.

Jones C and Spicer A (2009) Unmasking the Entrerpeneur. Cheltenham: Edward Elgar.

Lemke T (2001) 'The birth of bio-politics': Michel Foucault's lecture at the Collège de France on neo-liberal governmentality. Economy and Society 30: 190-207.

Meyer JW and Jepperson RL (2000) The 'actors' of modern society: The cultural construction of social agency. Sociological Theory 18(1): 100-120. 
Miller P and Rose N (2008) Governing the Present. Cambridge: Polity Press.

Niska, M and Vesala, KM (2011) Incompatible discourses and actor positions as pitfalls in SME policy implementation. Unpublished manuscript under review process.

Ogbor JO (2000) Mythicizing and reification in entrepreneurial discourse: Ideologycritique of entrepreneurial studies. Journal of Management Studies 37: 605-635.

Perren L and Jennings PL (2005) Government discourses on entrepreneurship: Issues of legitimization, subjugation, and power. Entrepreneurship Theory \& Practice 29: 173184.

Peters M (2001) Education, enterprise culture and the entrepreneurial self: A Foucauldian perspective. Journal of Educational Enquiry 2: 58-71.

Phillipson J, Gorton M, Raley M and Moxey A (2004) Treating farms as firms? The evolution of farm business support from productionist to entrepreneurial models. Environment and Planning C: Government and policy 22: 31-54. 
Pomerantz AM (1984) Agreeing and disagreeing with assessment: Some features of preferred/dispreferred turn shapes. In: Atkinson JM and Heritage J (eds) Structure of social action: Studies in conversation analysis. Cambridge: Cambridge University Press, 57-101.

Potter C and Tilzey M (2005) Agricultural policy discourses in the European postFordist transition: Neoliberalism, neomercantilism and multifunctionality. Progress in Human Geography 29(5): 1-20.

Pyysiäinen J (2010) Co-constructing a virtuous ingroup attitude? Evaluation of new business activities in a group interview of farmers. Text \& Talk 30(6): 701-721.

Rose N (1992) Governing the enterprising self. In: Heelas P and Morris P (eds) The Values of the Enterprise Culture: The Moral Debate. London: Routledge, 141-164.

Rose N (1993) Government, authority and expertise in advanced liberalism. Economy and Society 22: 283-299.

Rose N (1999) Powers of Freedom: Reframing Political Thought. Cambridge: Cambridge University Press. 
Rose N, O’Malley P and Valverde M (2006) Governmentality. Annual Review of Law and Social Science, 2: 83-104.

Ruuskanen P (1999) Rural development policy in Finland in the 1990s: Towards flexible specialization or spatial Taylorism? In: Kasimis C and Papadopoulos AG (eds) Local Responses to Global Integration. Aldershot: Ashgate, 223-244.

Speer SA (2002) What can conversation analysis contribute to feminist methodology? Putting reflexivity into practice. Discourse \& Society 13(6): 783-803.

Spillane JP, Reiser BJ and Reimer T (2002) Policy implementation and cognition: Reframing and refocusing implementation research. Review of Educational Research 72(3): 387-431.

Storey D (2005) Entrepreneurship, small and medium sized enterprises and public policies. In: Acs ZJ and Audretsch DB (eds) Handbook of Entrepreneurship Research: An Interdisciplinary Survey and Introduction. New York: Springer, 473-511. 
Vesala KM and Peura J (2005) Presentation of personal control in the rhetoric of farm families engaged in business diversification in Finland. Journal of Comparative Family Studies 36: 443-473.

Vesala KM and Rantanen T (eds) (2007) Argumentaatio ja Tulkinta: Laadullisen Asennetutkimuksen Lähestymistapa [Argumentation and interpretation: The qualitative attitude approach]. Helsinki: Gaudeamus.

Vihinen H and Vesala KM (eds) (2007) Maatilayritysten monialaistuminen maaseudun elinkeinopolitiikassa ja sen rakentuminen kuntatason kehittämiskohteena. [On-farm business diversification in rural industrial policy and how it is constructed at the municipality level as an object of development] Helsinki: Maa- ja elintarviketalouden tutkimuskeskus, Maa- ja elintarviketalous 114.

Watson T (2009) Entrepreneurial action, identity work and the use of multiple discursive resources: The case of a rapidly changing family business. International Small Business Journal 27: 251-274.

Wetherell M (1998) Positioning and interpretative repertoires: Conversation analysis and post-structuralism in dialogue. Discourse \& Society 9(3): 387-412. 


\title{
Appendix
}

\section{Notations used in the transcription of the interviews:}

\author{
Notation Explanation \\ word. A dot indicates a downward intonation at the end of an utterance \\ word, A comma indicates a constant intonation at the end of an \\ utterance, i.e. brief breaks within or between speech sequences \\ wo[rd Left-side brackets indicate where overlapping talk (between two \\ or more speakers) begins \\ wo]rd Right-side brackets indicate where overlapping talk ends \\ ((laughter)) Word(s) in double parentheses are used to indicate transcriber's \\ clarifying remarks, e.g. comments on what is happening in \\ addition to the talk \\ word Underlining is used to indicate an emphasis or accentuation of the \\ underlined word(s) or sound(s) \\ Two hyphens indicate a point where some part of the \\ commenting has been omitted
}

